\title{
Synthesis and Characterization of Some Ester-type Biolubricants of Soiabean Fatty Acids
}

\begin{abstract}
SORINA BORAN, SABINA NITU*
Politehnica UniversityTimisoara, Faculty of Industrial Chemistry and Environmental Engineering, 6 V. Parvan Blvd., 300223, Timisoara, România

Growing demands from industry for the use of eco-friendly lubricants led research towards finding environmentally friendly products with superior lubricating characteristics. Vegetable oils and synthetic ester oils are competitive base oils used to obtain lubricants with good physico-chemical, rheological and tribotechnical properties, biodegradable lubricants without negative environmental impacts. In this study we aimed the synthesis and characterization of bioesters with lubricant properties, using as acid component the soybean oil fatty acids in conjunction with the following hydroxyl compounds n-buthanol (P1) and 1,2propilenglycole $(P 2)$, respectively. These complex esters were synthesized in a microwave reactor in a single stage in the presence of the catalystat the reflux temperature. Characterization was carried out in the respective of structural point of view and as a lubricant.
\end{abstract}

Keywords: biolubricants, vegetable oils, fatty acid esters, microwave reactor

Due to biodegradability, low toxicity and low price, the vegetable oils can be used as an alternative source of lubricant, replacing with very good results esters, synthetic lubricants, particularly in sensitive areas in terms of ecological, such as forestry, agriculture or mining [1-4].

Evaluating biodegradability of mineral oils synthesized with bio lubricants based on vegetable oils, the biolubricants are found to be less harmful to the environment [5] and show better thermal stability compared to synthetic esters [6].

The purpose of modern technologies is to find energetic efficient processes and ecological ones that can replace the classical technologies. As examples are polymerization, which is a process with wide application [7-10], and esterification processes in bubble column reactors. As presented by Popa et all [11-14] polymers synthesized in a bubble gas column reactor are ecological ones, because they do not contain residual monomer. The energetic efficiency calculation of such a reactor is presented for some esterification processes in [15]. Because intensification of heat transfer of all thermal processes is an important technological issue, calculation of boiling heat transfer coefficients may be of high value [16-19].

To reduce the negative effects of industrial activities on the environment can be used the following solutions: reducing wastes by recycling some of these materials [ $20-$ 23], reusing wastes to obtain other useful products [2425] or to immobilize other hazardous waste [26-27] and replacing of raw materials with new products.

\section{Experimental part \\ Materials and methods}

The fatty acids esters were obtained in a microwave reactor, using as the acid component the soybean oil fatty acids, in conjunction with hydroxyl compounds, namely nbutanol to give compound P1 and 1,2-propyleneglycol to give compound $\mathrm{P} 2$, respectively. The reactions were developed in a single stage in the presence of the catalyst: p-toluenesulphonic acid, in the $0.4 \%$ proportion towards the acids from soybean oil fatty acids, at reflux temperature.
The possible reactions in these syntheses are the following:
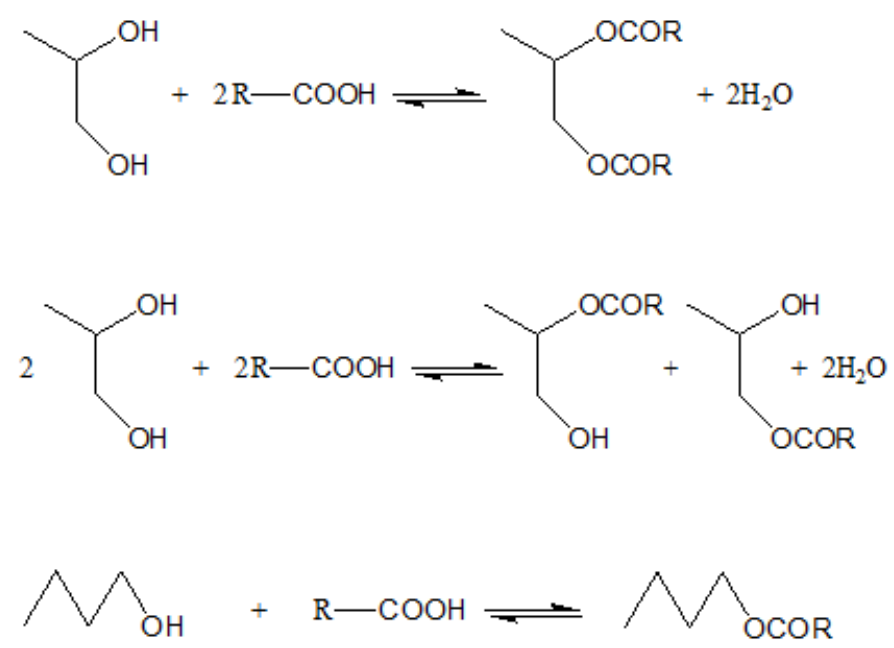

where $\mathrm{R}-\mathrm{COOH}=$ soybean oil fatty acids.

Synthetic variants thereof are shown in table 1.

The physico-chemical properties of fatty acids from soybean oil: appearance: viscous liquid without mechanical impurities; color: yellow; molecular weight, $\mathrm{g} /$ mole: 280 ; density at $20^{\circ} \mathrm{C}, \mathrm{g} / \mathrm{cm}^{3}: 0.89$; melting point, ${ }^{\circ} \mathrm{C}: 14-16$; acid number, $\mathrm{mg} \mathrm{KOH} / \mathrm{g}$ : 193.4; refraction index, la $20^{\circ} \mathrm{C}$ : 1.458 . The alcohols used are from Fluka. The characteristics of the chemical reactor with microwave heating are: model: DB-001; microwave power: $0 \sim 800 \mathrm{~W}$; microwave frequency: $50 \mathrm{MHz} 2450+$; Shaking: magnetic stirrer.

The variation of the acid number of the reaction mass according to the reaction time was the tracking reaction parameter.

For compound $\mathrm{P} 1$, synthesis parameters are drawn in table 2.

For compound $\mathrm{P} 2$, synthesis parameters are drawn in table 3.

From tables 1 and 2 it can be seen that the use of a chemical reactor with microwave heating, both reactions 


\begin{tabular}{|c|c|c|c|}
\hline \multirow[t]{2}{*}{ Raw materials } & \multirow[t]{2}{*}{$\mathrm{MU}$} & \multicolumn{2}{|c|}{ Synthesis variant abbreviations } \\
\hline & & P1 & P2 \\
\hline soybean oil fatty acids & mols & 1 & 1 \\
\hline n-butanol & mols & 1.2 & - \\
\hline 1,2-propilenglycol & mols & - & 0.55 \\
\hline p-toluenesulphonic acid & $\%$ & 0.4 & 0.4 \\
\hline \multicolumn{4}{|c|}{ Reaction conditions } \\
\hline Time of reaction & $\min$. & 180 & 215 \\
\hline Temperature of reaction & ${ }^{\gamma} \mathrm{C}$ & 118 & 180 \\
\hline
\end{tabular}

Table 2

REACTION PARAMETERS FOR THE ESTER P1

\begin{tabular}{|c|c|c|}
\hline Temperature, ${ }^{\circ} \mathrm{C}$ & Time, min & $\begin{array}{c}\text { Acid number, mg } \\
\mathrm{KOH} / \mathrm{g}\end{array}$ \\
\hline 70 & 0 & 132.26 \\
\hline 118 & 30 & 41.12 \\
\hline 118 & 60 & 34.26 \\
\hline 118 & 90 & 33.86 \\
\hline 118 & 120 & 27.16 \\
\hline 118 & 150 & 18.85 \\
\hline 118 & 180 & 5.92 \\
\hline
\end{tabular}

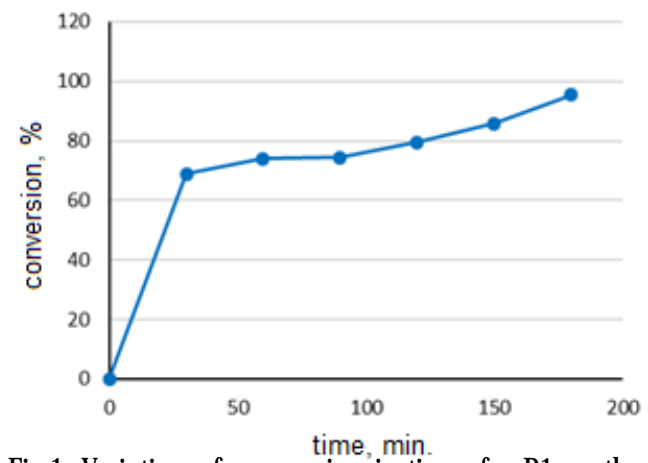

Fig.1. Variation of conversion in time, for P1 synthesis

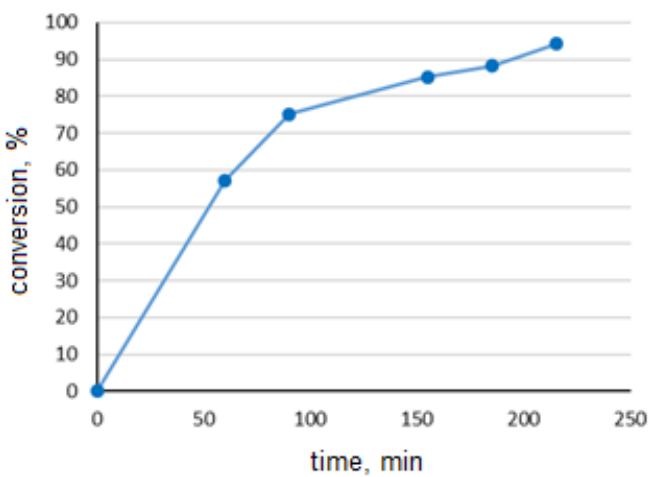

Fig. 2. Variation of conversion in time, for $P 2$ synthesis

are held in a much shorter time as compared with conventional esterification processes [28-29].

The graph in figure 1 shows the variation of conversion in time, and it can be observed a sharp increase in the conversion in the first 30 min followed by a slow rise, so
Table 1

THE SYNTHESIS VARIANTS OF ESTERS FROM SOYBEAN OIL FATTY ACIDS
Table 3

REACTION PARAMETERS FOR THE ESTER P2

\begin{tabular}{|c|c|c|}
\hline Temperature, ${ }^{\circ} \mathrm{C}$ & Time, $\min$ & $\begin{array}{c}\text { Acid number, } \\
\mathrm{mg} \mathrm{KOH} / \mathrm{g}\end{array}$ \\
\hline 160 & 0 & 173.42 \\
\hline 180 & 60 & 74.25 \\
\hline 180 & 90 & 43.21 \\
\hline 180 & 155 & 25.72 \\
\hline 180 & 185 & 20.5 \\
\hline 180 & 215 & 9.89 \\
\hline
\end{tabular}

that ultimately a high conversion yield of about $96 \%$ is obtained.

As in the case of $\mathrm{P} 1$ synthesis, the reaction to obtain the product P2 follows similar variation in the acid number and of the conversion in time (fig. 2).

Finally, the obtained results are very good, with a low acid number and a very good conversion.

Structural characterization of P1 and P2 esters synthesized: the dynamic viscosity - the viscometer type RV-Rheotest (EBV Prüfgeräte-Werk Medingen / Dresden); refractive index - Abbe refractometer at $200 \mathrm{C}$; density the pycnometer at $20^{\circ} \mathrm{C}$; the acid number - according to SR ISO 3682; saponification index - ISO 3657: 2013 iodine index - according to SR EN ISO 3961: 2013 A;

Evaluation of $\mathrm{P} 1$ and $\mathrm{P} 2$ synthesized esters as lubricant: flashpoint - according to SR 5489: 2008; the kinematic viscositythe, viscosity index respectively - with the viscometer Ubbelohde ASTM 445; scar diameter - ASTM D-4172; thermogravimetric analysis (TG) / (DTG) and differential scanning calorimetry (DSC) were performed with NETZSCH STA apparatus STA449F1A 449F1-0220-M. A quantity of between $3 \div 7 \mathrm{mg}$ sample was heated in a crucible of $\mathrm{Al}_{2} \mathrm{O}_{3}$, with the rate of $5^{\circ} \mathrm{C} / \mathrm{min}$., under a nitrogen atmosphere in the temperature range of $20 \div 600^{\circ} \mathrm{C}$.

\section{Results and discussions}

Physico-chemical properties of the synthesized esters (P1 and P2) are shown in table 4.

Both $\mathrm{P} 1$ and $\mathrm{P} 2$ products have the values of density, viscosity and refractive index comparable to those of soybean oil (standard). In comparison to the soybean oil, the iodine values corresponding to the synthesized compounds are smaller, which indicates a lower degree of unsaturation. In all cases, the acid number is below unity. 


\begin{tabular}{|l|c|c|c|}
\hline \multicolumn{1}{|c|}{ Property } & P1 & P2 & Soybean oil \\
\hline Density, $\rho^{20} / \mathrm{kg} \mathrm{m}^{-3}$ & 883.5 & 1142.3 & $919-925$ \\
\hline Refractive index, $\mathrm{nD}^{20}$ & 1.4598 & 1.4678 & $1.466-1.470$
\end{tabular}

\begin{tabular}{|c|c|c|c|}
\hline 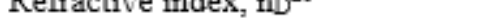 & & & \\
\hline Viscosity, $\eta^{20} / \mathrm{mPa} \mathrm{s}$ & 80.91 & 84.58 & 83.22 \\
\hline Saponification index, $\mathrm{mg} \mathrm{KOH} \mathrm{g} \mathrm{g}^{-1}$ & 220 & 124.1 & $189-195$ \\
\hline Acid number, $\mathrm{mg} \mathrm{KOH} \mathrm{g}{ }^{-1}$ & $<1$ & $<1$ & $<1$ \\
\hline Iodine index, $\mathrm{g} \mathrm{I}_{2} 100 \mathrm{~g}^{-1}$ & 110 & 80.2 & $120-140$ \\
\hline
\end{tabular}

PHYSICO-CHEMICAL PROPERTIES OF THE SYNTHESIZED ESTERS P1 AND P2

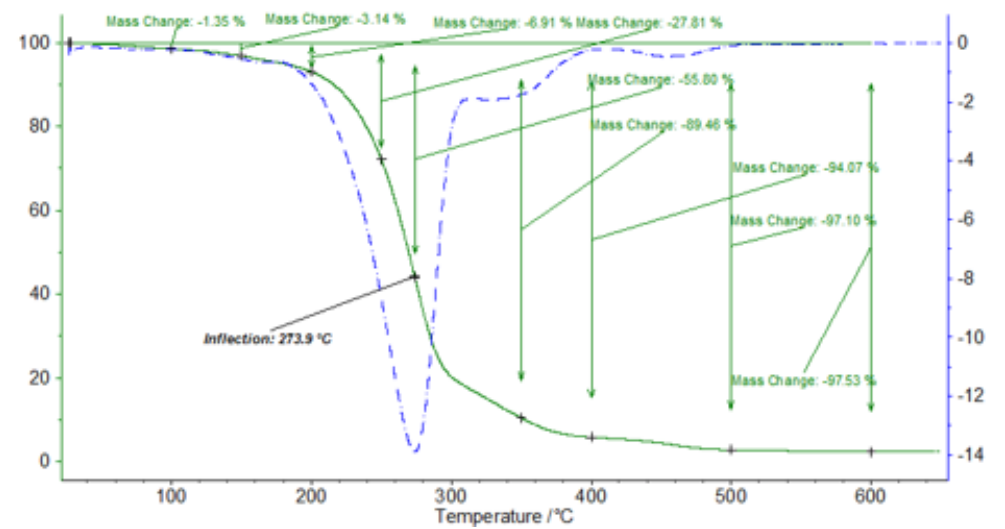

Fig.3. TG/DTG curves for P1 ester in nitrogen atmosphere

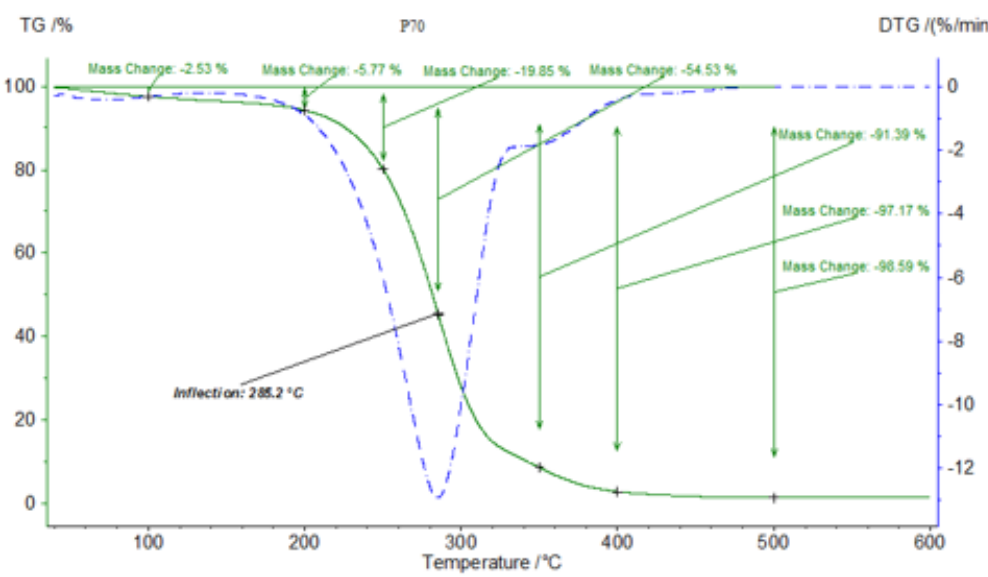

Figure 3 presents the TG/DIG curves ot the Pl ester in nitrogen atmosphere, and figure 4 presents the TG/DTG curves of the P2 ester in nitrogen atmosphere.

Figures 3 and 4 show that in both cases we have a good thermal behavior until about $200^{\circ} \mathrm{C}$, the temperature to which the weight loss is not significant. Over $250^{\circ} \mathrm{C}$ starts the rapidly losing of mass as the temperature increases. In the case of compound P1 the highest mass loss occurs at $273.9^{\circ} \mathrm{C}$, while in the case of compound $\mathrm{P} 2$ at the temperature of $285.2^{\circ} \mathrm{C}$. For both compounds $\mathrm{P} 1$ and $\mathrm{P} 2$, the total mass loss occurs in the range of $500-600^{\circ} \mathrm{C}$.

After characterization from physico-chemical point of view of an organic substance, esters synthesized were analyzed as lubricants.

In table 5 the rheological characteristics of soybean oil and the synthesized compounds $\mathrm{P} 1$ and $\mathrm{P} 2$ are presented.

From table 5 it is noted that the inflammation temperature and viscosity index show high values, that increase with increasing molecular weight and with decreasing capacity of evaporation respectively.

To determine the lubricating ability of these synthetic oils, the test with four balls was carried out, whose results are shown in table 6.

The results show that the species without additives and to a level test of 60 daN for 60 min, scar diameters are generally very good, placing it in the range of 0.47-0.61 $\mathrm{mm}$. Adding additive to oils result in a slight improvement in behavior in all cases. The compounds show a good compatibility with such synthetic anti-wear additives.

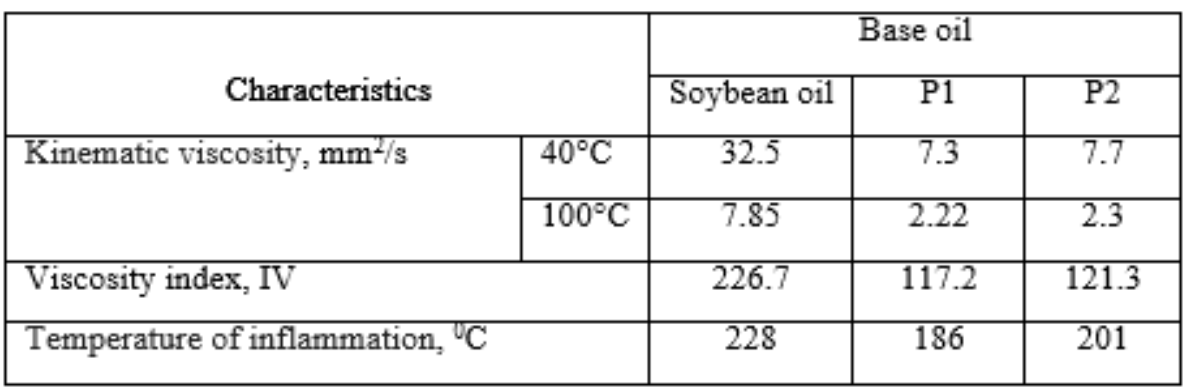

Table 5

RHEOLOGICAL CHARACTERISTICS OF VEGETABLE OILS AND OF SYNTHESIZED ESTERS 


\begin{tabular}{|c|c|c|c|c|c|c|}
\hline \multirow{3}{*}{ Compound } & Without additives & \multicolumn{2}{|c|}{$\begin{array}{l}\text { The addition of } 1.5 \% \\
\mathrm{Zn} \text { dithiophosphate }\end{array}$} & \multicolumn{2}{|c|}{$\begin{array}{l}\text { The addition } 1,5 \% \\
\text { Zn ditiocarbonat }\end{array}$} & \multirow{3}{*}{$\begin{array}{c}\text { Table } \mathbf{6} \\
\text { SCAR DIAMETER AND FOUR-BALL } \\
\text { TEST }\end{array}$} \\
\hline & Scar diameter, $\mathrm{mm}$ & Scar dia & $\mathrm{er}, \mathrm{mm}$ & Scar dia & eter, $\mathrm{mm}$ & \\
\hline & $\begin{array}{l}60 \mathrm{daN} \\
60 \mathrm{~min}\end{array}$ & $\begin{array}{l}40 \mathrm{daN} \\
60 \mathrm{~min}\end{array}$ & $\begin{array}{l}150 \mathrm{daN} \\
1 \mathrm{~min}\end{array}$ & $\begin{array}{l}40 \mathrm{daN} \\
60 \mathrm{~min}\end{array}$ & $\begin{array}{l}150 \mathrm{daN} \\
1 \mathrm{~min}\end{array}$ & \\
\hline P1 & 0.52 & 0.44 & 1.60 & 0.48 & 1.61 & \\
\hline P2 & 0.47 & 0.42 & 1.65 & 0.47 & 1.74 & \\
\hline Soybean oil & 0.61 & 0.46 & 1.77 & 0.56 & 1.90 & \\
\hline
\end{tabular}

\section{Conclusions}

The aim of this work was the synthesis and characterization of some bioesters using as the acid component fatty acids of soya bean oil in conjunction with various hydroxy compounds, namely n-butanol to give the compound $P 1$, and 1,2-propylene glycol to give the compound $\mathrm{P} 2$. The reactions developed in a single stage, in the presence of the catalyst, p-toluenesulfonic acid $(0.4 \%$ to the acids from soybean oil fatty acids) at reflux temperature.

By the use of a chemical reactor with microwave heating, both synthesis are held in a much shorter time as compared with the conventional esterification.

The esters thus synthesized have been characterized as lubricants, in this sense determining their flash point, kinematic viscosity and viscosity index, scar length for the species with or withoutadditives. Thermogravimetry (TG)/ (DTG) analyzes and calorimetric differential scanning (DSC) were also performed.

The obtained results have certified the possibility of using these compounds as lubricants, which are of outstanding quality in tribological fluids domain, having characteristic features of lubricating oils.

\section{References}

1.RUGGIEROA, A., D'AMATOB, R., MEROLAA, M., VALASEK, P., MÜLLER, M., Tribology International, 102, 2017, p. 529

2.YU, Q., HUANG, G., CAI, M., ZHOU, F., LIU, W., Tribology International, 95, 2016, p. 55

3.UCHIMOTO, T., IWAO, Y., IKEGAMI, Y., MURATA, T., SONOBE, T., MIYAGISHIMA, A., ITAI, S., International Journal of Pharmaceutics, 386, no. 1-2, 2010, p. 91

4.PANCHAL, T. M., PATEL, A., CHAUHAN, D. D., THOMAS, M., PATEL, J. V., Renewable and Sustainable Energy Reviews, 70, 2017, p. 65 5.MURILO, F., LUNA, T., CAVALCANTE, J. B., SILVA, F. O. N., CAVALCANTE J R., C. L., Tribology International, 92, 2015, p. 301 6.CAVALCANTE, M. I., DE C. ROCHA, N. R., MAIER, M. E., DE LIMA, D. A. P., NETO, A. D. M., DE BRITO, D. H. A., PETZHOLD, C. L., SCHANZ, M. T. G. F., RICARDO, N. M. P. S., Industrial Crops and Products, 62, 2014, p. 453

7.PLESU, N., ILIA, G., BANDUR, G., POPA, S., Journal of the Serbian Chemical Society, 70, no. 10, 2005, p. 1169
8.PLESU, N., ILIA, G., ILIESCU, S., POPA, A., BANDUR, G., POPA, S., Mat. Plast, 41, no.3, 2004, p.143

9.PLESU, N., BANDUR, G., MANOVICIU, I., POPA, S., JURCAU, D., Mat. Plast, 40, no.1, 2003, p. 21

10.PLESU, N., RAD, R., MANOVICIU, I., BANDUR, G., POPA, S., Rev. Chim. (Bucharest), 54, no. 8, 2003, p. 685

11.POPA, S., CSUNDERLIK, C., JASCANU, V., JURCAU, D., PLESU, N., Mat. Plast, 41, no. 2, 2004, p. 62

12.POPA, S., CSUNDERLIK, C., JASCANU, V., JURCAU, D., PLESU, N., Mat. Plast., 40, no. 4, 2003, p. 177

13.POPA, S., JASCANU, V., JURCAU, D., PLESU, N., Rev. Chim. (Bucharest), 54, no. 7, 2003, p. 595

14.POPA, S., CSUNDERLIK, C., FLOREA, S., JASCANU, V., PLESU, N., Rev. Chim. (Bucharest), 53, no. 4, 2002, p. 259

15.POPA, S.; BORAN, S., Mat. Plast., 53, no. 3, 2016, p. 410

16.KOHN, D., POPA, S., Experimental Heat Transfer, 12, no. 3, 1999, p. 193

17.POPA, S., BORAN, S., Thermal Science, 2015; DOI: 10.2298/ TSCI150728203P

18.POPA, S., BORAN, S., Rev. Roum. Chim., 61, no. 11-12, 2016, p. 851 19.POPA, S., BORAN, S., Rev. Rou. Chim., 60, no. 10, 2015, p. 991

20.MOSOARCA, G., NEGREA, P., MOTOC, M., CRACIUNESCU, M., ANGHEL, M., DAVID, D., Rev. Chim. (Bucharest), 60, no.6, 2009, p. 636 21.MOSOARCA, G., PODE, V., Rev. Chim. (Bucharest), 60, no.8, 2009, p. 836

22.MOSOARCA, G., NEGREA, P., VANCEA, C., MOTOC, M., ANGHEL, M., DAVID, D., Rev. Chim. (Bucharest), 61, no. 10, 2010, p. 983

23.MOSOARCA, G., NEGREA, A., J ournal of Environmental Protection and Ecology, 13, no. 1, 2012, p. 198

24.LAZAU, I., VANCEA, C., Romanian J ournal of Materials, 42, no.3, 2012, p. 270

25.VANCEA, C., LAZAU, I., Central European J ournal of Chemistry, 12, no.7, 2014, p. 804

26.LAZAU, I., VANCEA, C., MOSOARCA, G., Romanian J ournal of Materials, 43, no.2, 2013, p. 210

27.VANCEA, C., MOSOARCA, G., NEGREA, A., LATIA, A., JURCA, R.M., Romanian Journal of Materials, 46, no. 3, 2016, p. 296

28.MIRCI, L., BORAN, S., RO 122.453-B1, June 30, 2009

29.MIRCI, L., BORAN, S., LUCA, P., BOIANGIU, V., Technische Akademie Esslingen International Tribology Colloquium Proceedings, 2006, p. 236

Manuscript received: 15.11 .2016 